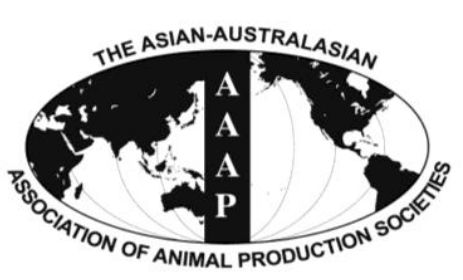

Open Access

Asian Australas. J. Anim. Sci.

Vol. 28, No. 1 : 143-150 January 2015

http://dx.doi.org/10.5713/ajas.14.0093

www.ajas.info

pISSN 1011-2367 elSSN 1976-5517

\title{
Effects of Bedding Material Composition in Deep Litter Systems on Bedding Characteristics and Growth Performance of Limousin Calves
}

\author{
J. Meng ${ }^{\text {a }}$, F. H. Shi ${ }^{\text {a }}$, Q. X. Meng*, L. P. Ren, Z. M. Zhou, H. Wu, and L. P. Zhao \\ College of Animal Sciences and Technology, State Key Laboratory of Animal Nutrition, \\ China Agricultural University, Beijing 100193, China
}

\begin{abstract}
The objective of this study was to evaluate the effects of different litter mixture compositions on bedding system temperature, $\mathrm{pH}$ and volatile fatty acid and ammonia- $\mathrm{N}\left(\mathrm{NH}_{3}-\mathrm{N}\right)$ content, and the serum physico-chemical parameters and growth indices of calves. Thirty-two Limousin calves $(280 \pm 20 \mathrm{~kg}$ ) were randomly assigned to four groups ( $\mathrm{n}=8$ for each group) according to the bedding system used: i) control with soil only (CTR); ii) mixture with 50\% paddy hulls (PH), 30\% saw dusts (SD), $10 \%$ peat moss (PM) and 10\% corn cobs (CC) (TRT1); iii) mixture with 15\% PH, 15\% SD, 10\% PM, 40\% CC, and 20\% corn stover (CS) (TRT2); iv) mixture with $30 \%$ PH, $10 \%$ PM, $40 \%$ CC, and $20 \%$ CS (TRT3). The litter material combinations of different treatments were based on the cost of bedding system materials in China. The cost of four treatments from low to high: Control<TRT1<TRT2<TRT3. The control was no-cost treatment. The diet consisted of $60.8 \%$ silage and $39.2 \%$ concentrate (dry matter [DM] basis). $\mathrm{The}^{\mathrm{N} H}-\mathrm{N}$ level (271.83 to $894.72 \mathrm{mg} / \mathrm{kg}$ ) was lowest for TRT1 $(\mathrm{p}<0.0001)$ and highest for TRT2 $(\mathrm{p}<0.0001)$. The acetate, propionate and butyrate levels were highest for the control group ( $\mathrm{p}<0.0001)$. In all the groups, the $\mathrm{pH}$ value $(6.90$ to 9.09$)$ increased at the beginning and later remained stable at below 9.09. The temperature of deep litter increased at the first week and reached the maximum $\left(42.1^{\circ} \mathrm{C}\right)$ on day 38 . $3,5,3^{\prime}-$ Triiodothyronine $\left(\mathrm{T}_{3}\right)$ levels in the TRT1 group animals $(\mathrm{p}<0.0001)$ were lower than those in the control and TRT2 animals. 3,5,3',5'Tetraiodothyronine $\left(\mathrm{T}_{4}\right)$ in the TRT1 group $(\mathrm{p}=0.006)$ was lower than that in the other treatment groups. Cortisol (COR) in the control and TRT1 group was lower $(\mathrm{p}<0.0001)$ than that in the TRT2 and TRT3 groups. Corticosterone $(\mathrm{CORt})$ in the control group was higher $(\mathrm{p}<0.0001)$ than that in the treatment groups. The findings indicate that the deep litter bedding systems provided better conditions for animal health and growth performance compared with the control system. Furthermore, the litter composition of TRT1 was found to be optimal among the three treatment groups. (Key Words: Bedding Systems, Volatile Fatty Acids, Serum Physico-chemical Parameters, Ammonia-N, Limousin Calves)
\end{abstract}

\section{INTRODUCTION}

The bedding system is widely used in beef cattle farms in Europe and Japan, but less use in China. Different bedding system materials and their mixtures have different characteristics (Kapuinen, 2001). Typically, bedding systems are made of paddy hulls and saw dusts. When the environmental temperature drops, animals need more energy to maintain their body temperature (Young, 1975; Christopherson, 1983; Fox et al., 1988; Eckert et al., 2000)

\footnotetext{
* Corresponding Author: Qingxiang Meng. Tel: +86-10-62733799, Fax: +86-10-6282-9099, E-mail: qxmeng@ cau.edu.cn

${ }^{a}$ These authors contributed equally to this work.

Submitted Feb. 9, 2014; Revised Apr. 29, 2014; Accepted Aug. 4, 2014
}

and their food consumption needs to increase (Olbrich et al., 1973; McDowell et al., 1976; Fox et al., 1988); these excessive energy requirements may even cause body weight loss (Webster, 1971; Christopherson, 1985). Therefore, there is a need for bedding systems that help animals maintain their body temperature and body weight during cold weather. Currently, the bedding systems in China is soil only, few farms use paddy hulls and saw dusts for bedding systems. China burns a lot of crop and forestry byproducts such as paddy hulls, saw dusts, corn stover, and corn cobs as a waste. Therefore, the scientific community and animal welfare groups have been actively searching for a better bedding system from the viewpoint of animal welfare and growth performance. 
The quality of a bedding system depends on the components, moisture content and aeration. A wellfermented bedding system makes a comfortable and warm setup for animals during winter. Paddy hulls, saw dusts, peat moss, corn cobs and corn stover are common residual products that are available cheaply in China. Paddy hulls, saw dusts and peat moss are the commonest material for bedding systems. Corn cobs and corn stover are less used for bedding systems. Because these materials are soft and porous, a combination of straw, peat and wood chips as bedding system material is thought to provide optimal height for the bedding system; moreover, such a bedding system would still have sufficient capacity to keep the animals from sinking into the bedding (Kapuinen, 2001). Corn cobs are porous and contains $45 \%$ cellulose, $35 \%$ hemicellulose and $15 \%$ lignin (Howard et al., 2003) and is a useful material in China for bedding systems. Corn stover are a more easily usable energy source for microorganisms compared to saw dusts and peat moss (Kirchmann, 1997). The total moisture content of a bedding system, including raw material and manure, should be 50\% to $60 \%$ (Campbell and Darbyshire, 1990; Rynk et al., 1992; Tiquia et al., 1998). Paddy hulls, saw dusts, corn cobs and corn stover are common residual products and their moisture is lower. The proportion of peat moss should be controlled within an appropriate range or the moisture content of the bedding system will exceed $60 \%$ at the end of the fermentation (Kapuinen, 2001). The composting temperature cannot be lowered by a decrease in oxygen but by aeration (Kapuinen, 2001). Therefore, an optimal bedding system should be porous and fluffy.

The objective of this study was to evaluate the effects of different proportions of litter components on the temperature, $\mathrm{pH}$, and volatile fatty acid (VFA) and ammonia- $\mathrm{N}\left(\mathrm{NH}_{3}-\mathrm{N}\right)$ content of the bedding system, as well as the calves' average daily gain (ADG) and serum physicochemical parameters. Through this study, we aimed to explore feasible and suitable bedding systems for use in Chinese cattle farms.

\section{MATERIALS AND METHODS}

\section{Experimental animals and the bedding systems}

Thirty-two Limousin calves (average age, 8 months; mean weight, $280 \pm 20 \mathrm{~kg}$ ) were randomly assigned to four groups ( $\mathrm{n}=8$ in each group). The treatments were: i) control bedding system with soil only (CTR); ii) bedding system with a deep litter mixture comprising $50 \%$ paddy hulls (PH), 30\% saw dusts (SD), $10 \%$ peat moss (PM), and $10 \%$ corn cobs (CC) (TRT1); iii) bedding system with a mixture comprising $15 \% \mathrm{PH}, 15 \% \mathrm{SD}, 10 \% \mathrm{PM}, 40 \% \mathrm{CC}$, and 20\% corn stover (CS) (TRT2); iv) bedding system with a mixture comprising $30 \% \mathrm{PH}, 10 \% \mathrm{PM}, 40 \% \mathrm{CC}$, and $20 \%$
CS (TRT3). Corn cobs and corn stover were ground using an ensilage cutter into 2 to $3 \mathrm{~mm}$ long pieces. Physical data of the materials used for the deep litter were analyzed (AOAC, 1990) before they were used in the bedding systems (Table 1).

The Limousin calves were housed in four separate uninsulated barns for each treatment. Each barn was 4 $\mathrm{m} \times 10 \mathrm{~m}$ in dimension and included a pit of size $2 \mathrm{~m} \times 10 \mathrm{~m}$ that was at a depth of $0.7 \mathrm{~m}$ into the floor (this depth was enough for a fermentation period of 7 weeks). The distance between the bottom and the top of the deep litter in each pit was $0.8 \mathrm{~m}$. Bulls were not kept in the barns until the temperature of the litter reached $15^{\circ} \mathrm{C}$ about $25 \mathrm{~cm}$ from the top of the deep litter in the pit, which required 7 days. The litter was ploughed about $30 \mathrm{~cm}$ in depth at noon every two days, in order to ensure that the oxygen content of the litter decreased more slowly. The calves were given a total mixed ration (TMR) diet, which consisted of $60.8 \%$ silage and $39.2 \%$ concentrate (Table 2). Calves were feed twice daily, at 0600 and $1800 \mathrm{~h}$; they had ad libitum access to TMR and fresh water throughout the experimental period. The experimental period was 56 days, which included 7 days of composting and 49 days of sampling. Samples of diets were collected once weekly for dry matter (DM) determination, and then composited by period. Samples of litter materials were collected before the trial for DM, carbon $(\mathrm{C})$, nitrogen $(\mathrm{N})$ and $\mathrm{C} / \mathrm{N}$ determination. The samples were dried in an oven at $65^{\circ} \mathrm{C}$ for $48 \mathrm{~h}$, and mill-ground to pass through a 1mm screen (FZ102, Shanghai Hongii instrument Co., Ltd., Shanghai, China) for chemical analysis. The experimental protocol was approved by the Animal Care and Use Committee of China Agricultural University.

\section{Analysis of the bedding systems}

The $\mathrm{C}, \mathrm{N}$, and $\mathrm{C} / \mathrm{N}$ of the litter material were determined using a rapid multi-element analyzer (Vario MAX; Elementar Analysensysteme GmbH, Hanau, Germany). Dry matter content of the litter material, silage and concentrate mix was determined by oven-drying the

Table 1. Composition of the three bedding systems (\%)

\begin{tabular}{lcccc}
\hline \multirow{2}{*}{ Components } & \multicolumn{4}{c}{ Treatments $^{1}$} \\
\cline { 2 - 5 } & Control & TRT1 & TRT2 & TRT3 \\
\hline Paddy hulls & 0 & 50 & 15 & 30 \\
Saw dusts & 0 & 30 & 15 & 0 \\
Peat moss & 0 & 10 & 10 & 10 \\
Corn cob & 0 & 10 & 40 & 40 \\
Corn stover & 0 & 0 & 20 & 20 \\
Soil & 100 & 0 & 0 & 0 \\
\hline
\end{tabular}

${ }^{1}$ The percentages shown represent volume ratios. Control with soil only; TRT1 mixture with 50\% paddy hulls (PH), 30\% saw dusts (SD), 10\% peat moss (PM) and 10\% corn cobs (CC); TRT2 mixture with 15\% PH, $15 \%$ SD, $10 \%$ PM, $40 \%$ CC, and $20 \%$ corn stover (CS); TRT3 mixture with $30 \% \mathrm{PH}, 10 \% \mathrm{PM}, 40 \% \mathrm{CC}$, and $20 \% \mathrm{CS}$. 
Table 2. Ingredients and composition of the basal diet ( $\mathrm{g} / \mathrm{kg}$ dry matter)

\begin{tabular}{|c|c|}
\hline Item & \\
\hline \multicolumn{2}{|l|}{ Ingredients } \\
\hline Silage & 608 \\
\hline Corn grain, ground & 290 \\
\hline Soybean meal & 66 \\
\hline Bean residue & 17 \\
\hline Sodium bicarbonate & 2.5 \\
\hline Calcium carbonate & 6.5 \\
\hline Salt & 3 \\
\hline Dicalcium phosphate & 5 \\
\hline Mineral and vitamin $\operatorname{mix}^{1}$ & 2 \\
\hline \multicolumn{2}{|l|}{ Chemical composition } \\
\hline Organic matter & 945.3 \\
\hline Crude protein & 101.1 \\
\hline Neutral detergent fiber & 565.1 \\
\hline Acid detergent fiber & 355.9 \\
\hline Calcium & 15.6 \\
\hline Phosphorus & 8.2 \\
\hline
\end{tabular}

samples at $65^{\circ} \mathrm{C}$ for $24 \mathrm{~h}$ using the methods described by Van Soest et al. (1991). The $\mathrm{N}$ content in the feed was determined using the rapid-N multi-element analyzer (Rapid-N III; Elementar Analysensysteme GmbH, Germany).

The temperature of the bedding systems was measured using a digital thermometer (TP101 pen recording thermometer, Shanghai Automation Instrument Factory, Shanghai, China) daily at $0800 \mathrm{~h}$ at a depth of $0.25 \mathrm{~m}$ from the top of the deep litter; readings were taken from five different parts and the average was calculated. The environmental temperature inside the barns was also measured.

For measurement of $\mathrm{pH}$, samples of deep litter from five different parts were collected daily at $0800 \mathrm{~h}$ at a depth of $0.15 \mathrm{~m}$ from the top. On each occasion, the samples were stored at about $4{ }^{\circ} \mathrm{C}$ in a container covered with a lid in order to preserve them and immediately transported to the laboratory for further analysis. For the analysis, $10 \mathrm{~g}$ of the sample was weighed and mixed with $50 \mathrm{~mL}$ distilled water and placed in a $4^{\circ} \mathrm{C}$ refrigerator for $60 \mathrm{~min}$. Then, the $\mathrm{pH}$ of the supernatant was measured using a digital $\mathrm{pH}$ meter (Sartorius Basic pH Meter PB-20, Sartorius AG, Goettingen, Germany).

For measurement of the VFA and $\mathrm{NH}_{3}-\mathrm{N}$ content, samples were collected from five different parts of the deep litter at the depth of $0.15 \mathrm{~m}$ from the top, at $0800 \mathrm{~h}$ at the end of the 4th week of sampling. Then, $5 \mathrm{~g}$ of the sample was mixed with $25 \mathrm{~mL}$ distilled water and placed in a $4{ }^{\circ} \mathrm{C}$ refrigerator for $60 \mathrm{~min}$. The solution was then filtered through a rapid filter paper and centrifuged at 3,000 rpm for $10 \mathrm{~min}$. Next, $1 \mathrm{~mL}$ of the supernatant was mixed with 0.2 $\mathrm{mL}$ of $250 \mathrm{~g} / \mathrm{L}(\mathrm{w} / \mathrm{v})$ metaphosphoric acid and left to stand in Eppendorf tubes for $30 \mathrm{~min}$. The VFA contents were determined use a gas chromatograph equipped (Agilent 6890N GC, Agilent Technologies, Santa Clara, CA, USA) with a capillary column $(30.0 \mathrm{~m} \times 320 \mu \mathrm{m} \times 0.5 \mu \mathrm{m}$, Catalog No:19091J-213, HP-INNOwax, Santa Clara, CA, USA) by the method of Erwin et al. (1961). For determining the $\mathrm{NH}_{3}$ $\mathrm{N}$ content, $5 \mathrm{~mL}$ of the supernatant was mixed with $1 \mathrm{~mL}$ of $20 \mathrm{~g} / \mathrm{L}(\mathrm{w} / \mathrm{v}) \mathrm{H}_{2} \mathrm{SO}_{4}$, and $\mathrm{NH}_{3}-\mathrm{N}$ was measured using an ultraviolet spectral photometer (UV-VIS 8500, Shanghai Techcomp, Shanghai, China) by the method of Broderick and Kang (1980).

\section{Analysis of the physico-chemical parameters and growth indices of the calves}

At the end of the sampling period, 20-mL blood samples were collected by venipuncture before feeding in the morning and stored in vacuum blood collection tubes. The blood samples were kept in an ice box until they were centrifuged at 3,000 rpm for $10 \mathrm{~min}$ at $4^{\circ} \mathrm{C}$. Serum samples were protected from light and separated in Eppendorf tubes and stored at $-4^{\circ} \mathrm{C}$ for determining the levels of thyrotropinreleasing hormone $(\mathrm{TRH}), 3,5,3^{\prime}$-triiodothyronine $\left(\mathrm{T}_{3}\right)$, 3,5,3',5'-tetraiodothyronine $\left(\mathrm{T}_{4}\right)$, cortisol (COR), and corticosterone (CORt) using a radioimmunoassay counter (Sn-69513, Shanghai Rihuan Photoelectric Instrument Co., Ltd, Shanghai, China).

The calves were weighed at the beginning and at the end of the trial to determine ADG. Individual dry matter intake (DMI) data was collected three times a week, together with animal weight was to adjust the feed to gain rates $(F / G)$ for calves of each treatments.

\section{Statistical analysis}

The data from the experiments were analyzed using the general linear model (SAS, 2004), and the means were compared for significance by the least square means procedure. The data of VFA, $\mathrm{NH}_{3}-\mathrm{N}$, serum physicochemical parameters and growth indices were subjected to analysis of variance using the following model:

$$
\mathrm{y}_{\mathrm{ij}}=\mu+\alpha_{\mathrm{i}}+\varepsilon_{\mathrm{ij}}
$$

where: $\mathrm{y}_{\mathrm{ij}}$, the experimental data; $\mu$, the general mean; $\alpha$, the treatment effect (I - Control, TRT1, TRT2, TRT2); and $\varepsilon$, the error term.

Effects of the factors were declared significant at $\mathrm{p}<0.05$ by Duncan's multiple range tests. 
Table 3. Physical data of the materials used in the bedding system

\begin{tabular}{lcccc}
\hline Components & $\mathrm{DM}(\%)$ & $\mathrm{C}(\%)$ & $\mathrm{N}(\%)$ & $\mathrm{C} / \mathrm{N}$ \\
\hline Paddy hulls & 88.64 & 37.01 & 0.70 & 52.63 \\
Saw dusts & 95.43 & 50.02 & 0.15 & 344.4 \\
Peat moss & 96.67 & 23.01 & 0.94 & 24.39 \\
Corn cobs & 96.56 & 45.19 & 0.75 & 59.94 \\
Corn stover & 88.33 & 40.58 & 1.10 & 36.79
\end{tabular}

DM, dry matter intake; $\mathrm{C}$, carbon; $\mathrm{N}$, nitrogen.

\section{RESULTS}

\section{Physical data of the litter material}

The DM, NDF, C, N, and $\mathrm{C} / \mathrm{N}$ values are shown in Table 3. The DM content of all the raw materials was higher than $88 \%$. Peat moss also had the lowest $\mathrm{C}$ content and $\mathrm{C} / \mathrm{N}$ ratio. The $\mathrm{N}$ content of all the raw materials was less than $1.1 \%$. The $\mathrm{C} / \mathrm{N}$ ratio was maximum in saw dusts, at $344.4 \%$; it was below $60 \%$ in the remaining materials.

\section{Temperature}

The difference in temperature between the environment and the treatments are shown in Figure 1. Environmental temperatures gradually reduced during the trials and lowest at $-13^{\circ} \mathrm{C}$. The temperatures of the bedding systems were higher than those of the environment. All the treatments show the same trend with regard to the temperature difference with the environment. The temperatures of all the bedding system treatments were higher than those of the control during the trail. The difference between the environment and the bedding systems was lower in the early part of the experiment, but it gradually increased and stabilized later. . The maximum difference in temperature between the environment and the bedding systems was observed for TRT3; it was $42.1{ }^{\circ} \mathrm{C}$ on day 38 . The temperatures of all the bedding system treatments tended to be similar towards the latter period of the experiment, between $24^{\circ} \mathrm{C}$ and $30^{\circ} \mathrm{C}$.

pH

The $\mathrm{pH}$ value of treatments are shown in Figure 2. The range of $\mathrm{pH}$ values of the treatments was 6.90 to 7.38 at the beginning of the trial. It gradually increased till it was

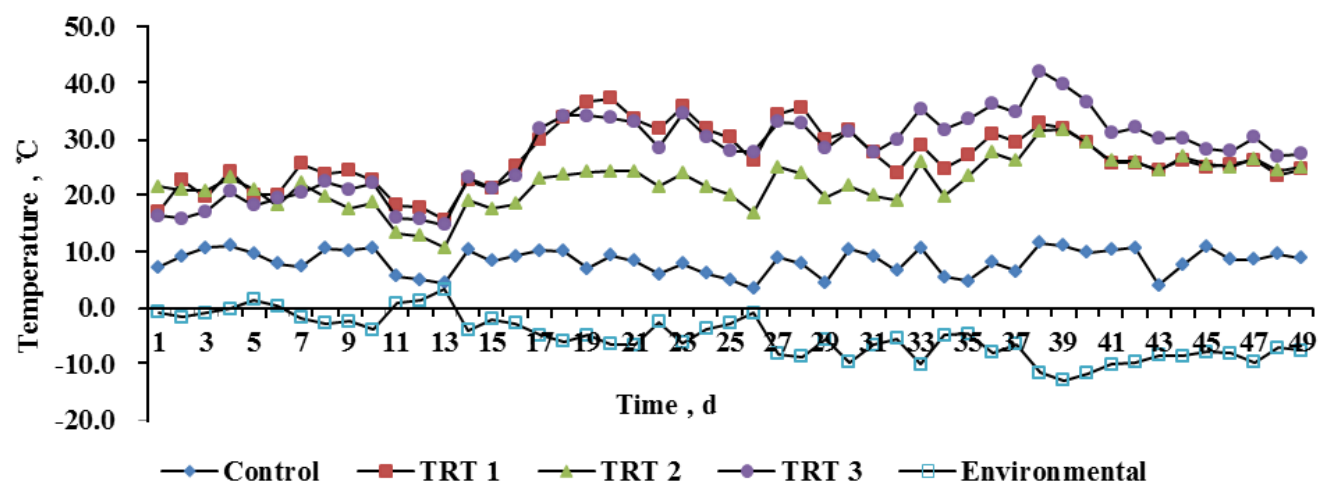

Figure 1. The difference in temperature between the environment and the treatments are shown in Figure 1. The temperature of the bedding systems was measured using a digital thermometer daily at $0800 \mathrm{~h}$ at a depth of $0.25 \mathrm{~m}$ from the top of the deep litter; readings were taken from five different parts and the average was calculated. The environmental temperature inside the barns was also measured.

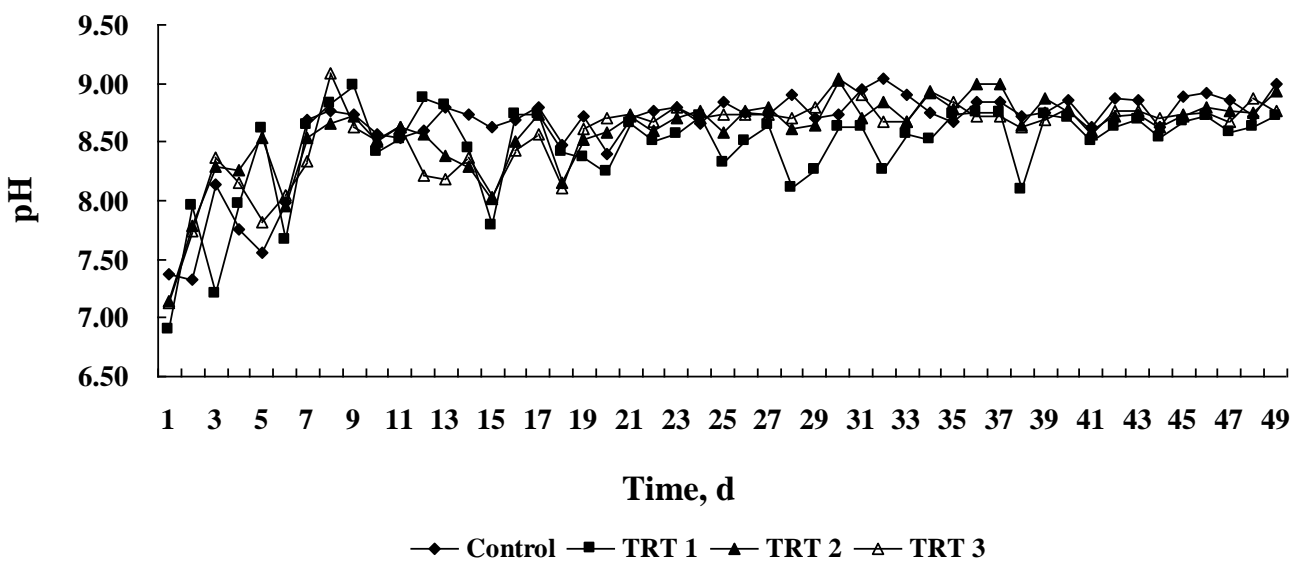

Figure 2. For measurement of $\mathrm{pH}$, samples of deep litter from five different parts were collected daily at $0800 \mathrm{~h}$ at a depth of $0.15 \mathrm{~m}$ from the top. On each occasion, the samples were stored at about $4^{\circ} \mathrm{C}$ in a container covered with a lid in order to preserve them and immediately transported to the laboratory for further analysis. For the analysis, $10 \mathrm{~g}$ of the sample was weighed and mixed with $50 \mathrm{~mL}$ distilled water and placed in a $4^{\circ} \mathrm{C}$ refrigerator for $60 \mathrm{~min}$. Then, the $\mathrm{pH}$ of the supernatant was measured using a digital $\mathrm{pH}$ meter. 
Table 4. Volatile fatty acid (VFA) and $\mathrm{NH}_{3}-\mathrm{N}$ content of the bedding systems at the end of the 4th week

\begin{tabular}{|c|c|c|c|c|c|c|}
\hline \multirow{2}{*}{ Element } & \multicolumn{4}{|c|}{ Treatment $^{1}$} & \multirow{2}{*}{ SEM } & \multirow{2}{*}{$\mathrm{p}$} \\
\hline & Control & TRT1 & TRT2 & TRT3 & & \\
\hline \multicolumn{7}{|l|}{$\overline{\text { VFA (mmol/kg) }}$} \\
\hline Acetate & $112.43^{\mathrm{a}}$ & $1.40^{\mathrm{b}}$ & $2.52^{\mathrm{b}}$ & $0.27^{\mathrm{b}}$ & 2.68 & $<0.01$ \\
\hline Propionate & $13.46^{\mathrm{a}}$ & $0.47^{\mathrm{b}}$ & $0.54^{\mathrm{b}}$ & $0^{\mathrm{b}}$ & 0.44 & $<0.01$ \\
\hline Butyrate & $6.00^{\mathrm{a}}$ & $0.20^{\mathrm{b}}$ & $0.20^{\mathrm{b}}$ & $0^{\mathrm{b}}$ & 0.15 & $<0.01$ \\
\hline $\mathrm{NH}_{3}-\mathrm{N}(\mathrm{mg} / \mathrm{kg})$ & $542.12^{\mathrm{b}}$ & $271.83^{c}$ & $894.72^{\mathrm{a}}$ & $549.20^{\mathrm{b}}$ & 15.63 & $<0.01$ \\
\hline
\end{tabular}

SEM, standard error of the mean; $\mathrm{NH}_{3}-\mathrm{N}$, ammonia-N.

${ }^{1}$ Control with soil only; TRT1 mixture with $50 \%$ paddy hulls (PH), 30\% saw dusts (SD), $10 \%$ peat moss (PM) and $10 \%$ corn cobs (CC); TRT2 mixture with $15 \% \mathrm{PH}, 15 \%$ SD, $10 \%$ PM, $40 \%$ CC, and $20 \%$ corn stover (CS); TRT3 mixture with $30 \%$ PH, $10 \%$ PM, $40 \%$ CC, and $20 \%$ CS.

Means in the same row with different superscripts are significantly different $(\mathrm{p}<0.05)$.

around 8.50 for most of the experimental period. The maximum $\mathrm{pH}$ value observed was about 9.04. The values for TRT1 were lower than those for the other treatments at some time points.

\section{Volatile fatty acid and ammonia-N content}

Acetate, propionate and butyrate levels in the control were significantly higher than those in the treatment groups ( $\mathrm{p}<0.01$; Table 4). Propionate and butyrate was not detected in the TRT3 system. The $\mathrm{NH}_{3}-\mathrm{N}$ content was significantly higher $(\mathrm{p}<0.01)$ for TRT2 and lower $(\mathrm{p}<0.01)$ for TRT1.

\section{Serum physico-chemical parameters}

Effects of the bedding systems on the serum physicochemical parameters are shown in Table 5. The bedding system had no significant effects on TRH. The $\mathrm{T}_{3}$ level in the TRT1 group was significantly lower $(\mathrm{p}<0.01)$ than that in the control and TRT2 groups. The $\mathrm{T}_{4}$ level in the TRT1 group was significantly lower $(p<0.01)$ than that in the other treatment groups. The COR values for TRT2 and TRT3 were significantly higher $(p<0.01)$ than those for the control and TRT1 groups. The CORt values for the control were significantly higher $(\mathrm{p}<0.01)$ than those for the TRT1 and TRT2 groups.

\section{Growth indices}

The effects of the bedding system on growth performance are shown in Table 6. Although the ADG for the TRT1 group was higher than that for the other groups, the difference was not significant. The value of DMI was not significantly different between the groups. The F/G value for the TRT1 was lower than that for the control

Table 5. Effects of the bedding systems on serum physico-chemical parameters in Limousin bulls

\begin{tabular}{lcccccc}
\hline \multirow{2}{*}{ Parameter } & \multicolumn{2}{c}{ Treatment $^{1}$} & \multirow{2}{*}{ SEM } & \multirow{2}{*}{$\mathrm{p}$} \\
\cline { 2 - 5 } & Control & TRT1 & TRT2 & TRT3 & & \\
\hline Thyrotropin-releasing hormone $(\mathrm{pg} / \mathrm{mL})$ & 3.29 & 3.37 & 2.04 & 1.94 & 0.88 & 0.52 \\
$3,5,3^{\prime}-$ Triiodothyronine $(\mathrm{ng} / \mathrm{mL})$ & $2.81^{\mathrm{a}}$ & $2.20^{\mathrm{b}}$ & $2.95^{\mathrm{a}}$ & $2.72^{\mathrm{ab}}$ & 0.19 & $<0.001$ \\
$3,5,3^{\prime}, 5^{\prime}-$ Tetraiodothyronine $(\mathrm{ng} / \mathrm{mL})$ & $177.04^{\mathrm{a}}$ & $155.50^{\mathrm{b}}$ & $183.68^{\mathrm{a}}$ & $182.44^{\mathrm{a}}$ & 5.80 & 0.006 \\
Cortisol $(\mathrm{ng} / \mathrm{mL})$ & $57.06^{\mathrm{b}}$ & $56.38^{\mathrm{b}}$ & $80.97^{\mathrm{a}}$ & $73.91^{\mathrm{a}}$ & 5.51 & $<0.001$ \\
Corticosterone $(\mathrm{pg} / \mathrm{mL})$ & $519.74^{\mathrm{a}}$ & $401.12^{\mathrm{b}}$ & $414.10^{\mathrm{ab}}$ & $391.82^{\mathrm{b}}$ & 39.11 & $<0.001$ \\
\hline
\end{tabular}

SEM, standard error of the mean.

${ }^{1}$ Control with soil only; TRT1 mixture with 50\% paddy hulls (PH), 30\% saw dusts (SD), $10 \%$ peat moss (PM) and 10\% corn cobs (CC); TRT2 mixture with $15 \% \mathrm{PH}, 15 \%$ SD, $10 \%$ PM, $40 \%$ CC and $20 \%$ corn stover (CS); TRT3 mixture with $30 \% \mathrm{PH}, 10 \%$ PM, $40 \%$ CC, and $20 \%$ CS.

Means in the same row with different superscripts are significantly different $(\mathrm{p}<0.05)$.

Table 6. Effects of the bedding systems on growth indices in Limousin bulls

\begin{tabular}{lcccccc}
\hline \multirow{2}{*}{ Growth index } & \multicolumn{3}{c}{ Treatment } & \multirow{2}{*}{ SEM } & \multirow{2}{*}{$\mathrm{p}$} \\
\cline { 2 - 4 } & Control & TRT1 & TRT2 & TRT3 & & \\
\hline Initial weight $(\mathrm{kg})$ & 291.00 & 285.33 & 278.17 & 268.58 & 17.22 & 0.81 \\
Final body weight $(\mathrm{kg})$ & 332.83 & 330.67 & 313.00 & 305.50 & 19.77 & 0.72 \\
Average daily gain $(\mathrm{G})(\mathrm{kg})$ & 0.85 & 0.93 & 0.71 & 0.75 & 0.11 & 0.50 \\
Dry matter intake (F) $(\mathrm{kg})$ & 4.87 & 4.78 & 4.87 & 4.78 & 0.06 & 0.49 \\
Feed conversion ratio (F/G) & 6.37 & 5.40 & 8.07 & 6.56 & 0.90 & 0.25 \\
\hline
\end{tabular}

SEM, standard error of the mean.

${ }^{1}$ Control with soil only; TRT1 mixture with $50 \%$ paddy hulls (PH), 30\% saw dusts (SD), $10 \%$ peat moss (PM), and $10 \%$ corn cobs (CC); TRT2 mixture with $15 \% \mathrm{PH}, 15 \%$ SD, $10 \%$ PM, $40 \%$ CC, and $20 \%$ corn stover (CS); TRT3 mixture with 30\% PH, 10\% PM, $40 \%$ CC, and $20 \%$ CS.

Means in the same row with different superscripts are significantly different $(\mathrm{p}<0.05)$. 
group, but there was no significant difference between the treatment groups (TRT1, TRT2, and TRT3).

\section{DISCUSSION}

In this study, we have investigated the characteristics of bedding systems comprising different compositions of litter material, as well as their effects on the health of animals. In general, we found that the bedding systems formed by fermentation of deep litter performed better than the control system that contained soil only. The different characteristics and their effects are explained in the paragraphs below.

The raw materials used in our trials had high DM content (above 88\%); therefore, the moisture content was low. Lower moisture content prevents the growth of mold; therefore the materials had the appropriate moisture content. It has been reported that $\mathrm{C} / \mathrm{N}$ ratio of 25 to 35 is appropriate for composting (Waksman and Hutchings, 1936; Waksman and Cordon, 1939; Hoyle and Mattingly, 1954; Gray et al., 1971b; Hong et al., 1983; Rynk et al., 1992). The nitrogen loss in a compost with a $\mathrm{C} / \mathrm{N}$ ratio of 25 to 35 is $30 \%$ (Eklind et al., 2000). Low nitrogen concentration could have a negative influence on composting temperature. Thus, animal waste leads to a nitrogen source which is required for maintenance of optimal composting temperature in bedding systems.

In our experiment, the fermentation caused the bedding materials to reach a pleasant temperature so that the animals were comfortable. Kapuinen (2001) reports that the moisture content and carbon supply in deep litter are the most important factors that affect the composting temperature. The $\mathrm{C} / \mathrm{N}$ ratio of the materials used in this study was in the range of 24.39 to 34.44 , which has been reported to correspond to the optimal composting temperature (Hong et al., 1983). Therefore, compared with the control system, all the treatments with bedding systems provided external heat that assisted the animals' resistance to low temperature. The composition ratio of a deep litter system may have different effects on fermentation and therefore, the temperature of the bedding system. Kapuinen (2001) supposed that the lack of oxygen and low degradation in deep litter would lead to a low composting temperature. Moreover, Suler and Finestein (1977) found that composting occurred at a faster rate at an oxygen concentration of $18 \%$ compared to $10 \%$. In our experiment, TRT1 and TRT3 had a higher temperature than TRT2 from day 8 to 39 of composting; this was probably attributable to the high proportion of paddy hulls in the former treatments. It is possible that the porous texture of paddy hulls improves the breathability and therefore oxygen concentration of the bedding system, which is beneficial to fermentation.

The $\mathrm{pH}$ values determined in the present study were attributable to the ammonia produced by the fermentation of animal waste. Dewes (1996) reported that high fermentation temperature increases the potential for loss of ammonia. High ammonia in a bedding system causes a high $\mathrm{pH}$ value. That TRT1 had some time points with a lower $\mathrm{pH}$ than other treatments may have been due to the materials in this bedding system were fermenting at a higher temperature. The $\mathrm{pH}$ values are believed to reflect the ammonia content of deep litter, and animal feces and urine are the main sources of ammonia in bedding systems. Therefore, the high $\mathrm{pH}$ values observed in the present bedding systems maybe because the materials used have good permeability for ammonia.

In our study, the VFA content was lower in the treatment groups compared to the control; it is possible that the soft and porous structure of the bedding system led to easy loss of VFAs. Acetate formed the largest portion of VFAs in present study. It has been reported that acetic acid may cause erosion of the teeth in people who handle silicone sealers in the car industry without taking preventive measures (Ernstgard et al., 2005). High concentrations of acetic acid may have a similar effect on the health of calves. Thus, low acetate in bedding systems was good for animal welfare. Low $\mathrm{NH}_{3}-\mathrm{N}$ in the environment is associated with good animal health (Hickey et al., 2002). From our results, it seems that the composition of TRT1 was ideal for the utilization of $\mathrm{NH}_{3}-\mathrm{N}$ by microorganisms, as the $\mathrm{NH}_{3}-\mathrm{N}$ content was lowest for this group. According to Misselbrook and Powell (2005), in contrast with concrete surfaces, bedding systems allow the retention of urine on their absorbent surface layer and reduce ammonia emission. The $\mathrm{NH}_{3}-\mathrm{N}$ level was significantly higher in the TRT2 group; this was probably caused by the high DMI and low ADG in the animals, which caused excess animal waste. Similarly, the low DMI and high ADG in the TRT1 group may have caused the lesser animal waste and lower $\mathrm{NH}_{3}-\mathrm{N}$.

Thyrotropin-releasing hormone is a hypothalamic tripeptide that plays a role in stress response in animals (Arunabha Ray, 2006). TRT1 showed a significant lower for 3,5,3'-Triiodothyronine $\left(\mathrm{T}_{3}\right), 3,5,3^{\prime}, 5^{\prime}$-Tetraiodothyronine $\left(\mathrm{T}_{4}\right), \mathrm{COR}$, and corticosterone. Previous experiments have shown that $\mathrm{T}_{3}$ could provide feedback at the level of the hypothalamus to down regulate TRH synthesis (Segerson et al., 1987). Moreover, concentrations of $\mathrm{T}_{4}$ in the serum of cattle were decreased to below detectable levels by daily $\mathrm{T}_{3}$ injections (Thrift et al., 1999; Radcliff et al., 2001). High levels of ammonia could affect the respiratory system (Hickey et al., 2002) and thereby increase the stress level. The lower levels of $\mathrm{T}_{3}$ and $\mathrm{T}_{4}$ in TRT1 may be due to the lower concentration of $\mathrm{NH}_{3}-\mathrm{N}$ in this group. It is proved that lower $\mathrm{NH}_{3}-\mathrm{N}$ decreased the stress. Cortisol and corticosterone levels were significantly lower in TRT1. Cortisol, also known as hydrocortisone, is a steroid 
hormone (more specifically a glucocorticoid) produced by the zona fasciculata of the adrenal cortex (Scott, 2008). Lower COR and corticosterone may be attributable to the warm environment; that is, lower temperatures may induce stress in animals. Cortisol and corticosterone plays an important role in glycogenolysis, the breaking down of glycogen to glucose-1-phosphate and glucose, in liver and muscle tissue (Palme, 2000). It has been shown that animal raised on bedding systems could resistance to cold weather and reduce the stress.

Most researchers report that floor type has no effect on DMI (Levy et al., 1970; Andersen et al., 1991). It is reported that bulls housed from 4 to 5 months of age (507 $\mathrm{kg}$ live weight) in slatted and straw-bedded pens have similar food intake (Levy et al., 1970). Although there was no significant difference in the intake of DM between groups in this trial, TRT1 and TRT3 showed lower DMI. Fallon and Harte (1985) found lower carcass gains in cattle housed on slatted floors compared to those housed on solid floors bedded with saw dusts. This was similar to our study, where TRT1 showed higher ADG compared with control though the difference in ADG was not significant; this was probably because of the high proportion of saw dusts, suitable temperature, low VFA and low $\mathrm{NH}_{3}-\mathrm{N}$ with this system. TRT1 showed a higher feed conversion ratio although there was no significant difference in this trial. The TRT1 system is, therefore, associated with good economic benefits in this trial.

\section{CONCLUSION}

The deep litter systems had higher temperature and lower VFAs compared with the control system. Moreover, the animals housed on the deep litter bedding systems had lower levels of stress-related hormones. The mixture used in Treatment 1 (50\% paddy hulls, 30\% saw dusts, $10 \%$ peat moss and $10 \%$ corn cob) may be optimal for bedding systems, based on the results of this study.

\section{ACKNOWLEDGMENTS}

This study was financially supported by the Earmarked Fund for Modern Agro-Industry Technology Research System (Beef Cattle and Yaks, CARS-38), the National Scientific Supporting Fund (2008BADA7B04), and Beijing Supporting Central College Fund (201202910411136).

\section{REFERENCES}

Andersen, H. R., C. C. Krohn, J. Foldager, L. Munksgaard, and S. Klastrup. 1991. Influence of housing and feeding on behaviour, feed intake, growth and carcass and meat quality. National Institute of Animal Science, Denmark. pp. 39.
AOAC. 1990. Official Methods of Analysis, 15th ed. Association of Official Analytical Chemists, Inc., Arlington, VA, USA.

Broderick, G. A. and J. H. Kang. 1980. Automated simultaneous determination of ammonia and total amino acids in ruminal fluid and in vitro media. J. Dairy Sci. 63:64-75.

Campbell, C. D. and J. F. Darbyshire. 1990. The composting of tree bark in small reactors - self-heating experiments. Biol. Wastes 31:145-161.

Christopherson, R. J. 1985. Management and housing of animals in cold environments. Stress Physiology in Livestock. Volume II. Ungulates. CRC Press, Florida, USA. pp. 175-194.

Dewes, T. 1996. Effect of $\mathrm{pH}$, temperature, amount of litter and storage density on ammonia emissions from stable manure. J. Agric. Sci. 127:501-509.

Eckert, R., D. W. Randall, and K. Burggren, French. 2000. Tierphysiologie, 3rd ed. Georg Thieme Verlag, Stuttgart, Germany.

Eklind, Y. and H. Kirchmann. 2000. Composting and storage of organic household waste with different litter amendments. II: nitrogen turnover and losses. Bioresour. Technol. 74:125-133

Ernstgard, L., A. Iregren, B. Sjogren, and G. Johanson. 2006. Acute effects of exposure to vapours of acetic acid in humans. Toxicol. Lett. 165:22-30

Erwin, E. S., G. J. Marco, and E. M. Emery. 1961. Volatile fatty acid analyses of blood and rumen fluid by gas chromatography. J. Dairy Sci, 44:1768-1771.

Fallon, R. J. and F. J. Harte. 1985. Effect of methods of introducing purchased calves to ad libitum systems of warm milk replacer feeding on their performance. Irish J. Agric. Res. 24:21-32.

Fox, D. G., C. J. Sniffen, and J. D. O'Connor. 1988. Adjusting nutrient requirements of beef cattle for animal and environmental variations. J. Anim. Sci. 66:1475-1495.

Gray K. R., K. Sherman, and A. J. Biddlestone. 1971. Review of composting. Part 2. The practical process. Process Biochemistry 5:22-28.

Hickey, M. C., P. French, and J. Grant. 2002. Out-wintering pads for finishing beef cattle: animal production and welfare. Anim. Sci. 75:447-458.

Hong J. H., J. Matsuda, and Y. Ikeuchi. 1983. High rapid composting of dairy cattle manure with crop and forest residues. Transactions of the ASAE. Am. Soc Agric. Eng. 26:533-541.

Hoyle, D. A. and G. E. G. Mattingly. 1954. Studies on compostins prepared from waste materials. I.-Preparation, nitrogen losses and changes in 'soluble nitrogen'. J. Sci. Food Agric. 5:54-64

Kapuinen, P. 2001. Deep litter systems for beef cattle housed in uninsulated barns: Part 1, height increase, carrying capacity and specific counter-pressure of aeration of deep litters. J. Agric. Eng. Res. 79:419-428.

Kapuinen, P. 2001. Deep litter systems for beef cattle housed in uninsulated barns, Part 2: Temperatures and nutrients. J. Agric. Eng. Res. 80:87-97.

Levy, D., Z. Holzer, and R. Volcani. 1970. Concrete slatted floors vs. bedding for fattening Israeli-Friesian bull calves. J. Anim. Sci. 31:816-820.

McDowell, R. E., N. W. Hooven, and J. K. Camoens. 1976. Effect of climate on performance of Holsteins in first lactation. J. 
Dairy Sci. 59:965-973.

Misselbrook, T. H. and J. M. Powell. 2005. Influence of bedding material on ammonia emissions from cattle excreta. J. Dairy Sci. 88:4304-4312.

Young, B. A. 1975. Effects of winter acclimatization on resting metabolism of beef cows. Can. J. Anim. Sci. 55:619-625.

Olbrich, S. E., F. A. Martz, and E. S. Hilderbrand. 1973. Ambient temperature and ration effects on nutritional and physiological parameters of heat and cold tolerant cattle. J. Anim. Sci, 37:574-580.

Palme, R., C. Robia, W. Baumgartner, and E. Möstl. 2000. Transport stress in cattle as reflected by an increase in faecal cortisol metabolite concentrations. Vet. Rec. 146:108-109.

Ray, A. 2006. Modulation by thyrotropin releasing hormone (TRH) of stress responses in rats. Front. Neuroendocrinol. 27:154.

Radcliff, R. P., K. J. Lookingland, L. T. Chapin, and H. A. Tucker. 2001. Pituitary adenylate cyclase-activating polypeptide induces secretion of growth hormone in cattle. Domest. Anim. Endocrinol. 21:187-196.

Rynk, R., M. van de Kamp, G. B. Willson, M. E. Singley, T. L. Richard, J. J. Kolega, F. R. Gouin, L. Jr. Laliberty, D. Kay, D. W. Murphy, H. A. J. Hoitink, and W. F. Brinton. 1992. OnFarm Composting Handbook. Northeast Regional Agricultural Engineering Service, Cooperative Extention, NRAES No. 54. pp. 1-186.

Scott, E. 2008. Cortisol and stress: How to stay healthy. http://stress.about.com/od/stresshealth/a/cortisol.htm. Accessed June 1, 2014
Segerson, T. P., J. Kauer, H. C. Wolfe, H. Mobtaker, P. Wu, I. M. Jackson, and R. M. Lechan. 1987. Thyroid hormone regulates TRH biosynthesis in the paraventricular nucleus of the rat hypothalamus. Science 238:78-80.

Suler, D. J. and M. S. Finstein. 1977. Effect of temperature, aeration, and moisture on $\mathrm{CO}_{2}$ formation in bench-scale, continuously thermophilic composting of solid waste. Appl. Environ. Microbiol. 33:345-350.

Thrift, T. A., A. Bernal, A. W. Lewis, D. A. Neuendorff, C. C. Willard, and R. D. Randel. 1999. Effects of induced hypothyroidism or hyperthyroidism on growth and reproductive performance of Brahman heifers. J. Anim. Sci. 77:1833-1843.

Tiquia, S. M., N. F. Y. Tam, and I. J. Hodgkiss. 1998. Changes in chemical properties during composting of spent pig litter at different moisture contents. Agric. Ecosyst. Environ. 67:79-89.

Van Soest, P. J., J. B. Robertson, and B. A. Lewis. 1991. Methods for dietary fiber, neutral detergent fiber, and nonstarch polysaccharides in relation to animal nutrition. J. Dairy Sci. 74:3583-3597.

Waksman, S. A. and I. J. Hutchings. 1936. Decomposition of lignin by microorganisms. Soil Sci. 42:119-130.

Waksman, S. A. and T. C. Cordon. 1939. Thermophilic decomposition of plant residues in composts by pure and mixed cultures of microorganisms. Soil Sci. 47:217-226.

Webster, A. J. 1971. Prediction of heat losses from cattle exposed to cold outdoor environments. J. Appl. Physiol. 30:684-690. 